\title{
Zalecenia komitetu ekspertów działającego w ramach projektu EuSANH dla ministra zdrowia w sprawie organizacji skriningów populacyjnych
}

\author{
Magdalena Bielska-Lasota', Anna Dębska' ${ }^{1}$, Dorota Cianciara², \\ Maria Piotrowicz ${ }^{1}$, Mirosław J. Wysocki ${ }^{1}$
}

\section{Experts Committee recommendations to the Minister of Health on the organizing population screening with regard to the European Science Advisory Network for Health}

W obliczu wielu wyzwań, w tym starzenia się społeczeństwa i zagrożenia chorobami nowotworowymi, Unia Europejska podejmuje szereg działań zapobiegających przedwczesnym zgonom. Nowotwory, obok chorób układu krążenia, od kliku lat są główną przyczyną zgonów w Europie [1]. Jednym z narzędzi mających wpłynąć na zmniejszenie umieralności są skriningi populacyjne.

W związku z potrzebą opracowania nowej edycji programu zwalczania raka zasadne jest przypomnienie kluczowych dokumentów sporządzonych w celu osiągnięcia najwyższej skuteczności zdrowotnej i ekonomicznej organizowanych masowych badań przesiewowych w kierunku wczesnego wykrywania nowotworów (skriningów populacyjnych) w krajach UE. Jest szczególnie ważne, aby osoby wspierające, organizujące i wdrażające skrining w Polsce miały dostęp do tych dokumentów.

Skrining jest interwencją skierowaną do wybranej populacji. Jego celem jest zmniejszenie umieralności z powodu określonych chorób, w tym nowotworów [2]. Organizacja skrinigu jest działaniem kompleksowym i wieloetapowym — poczynając od rozpoznania istniejącego stanu wiedzy w tym zakresie i otwarcia społecznej debaty, na zapewnieniu finansowania, stabilności organizacyjnej i podtrzymywaniu społecznego zaufania kończąc [2]. W projektowaniu skriningu wykorzystuje się przede wszystkim wiedzę epidemiologiczną, onkologiczną, jak również wiedzę z zakresu organizacji i zarządzania. Równie ważna jest wiedza o komunikowaniu się.

Udane wdrożenie masowych badań przesiewowych w kierunku raka wymaga akceptacji społecznej, wykorzysta- nia najlepszych praktyk opartych na dowodach oraz kontroli i weryfikacji jakości w każdej fazie ich realizacji [2]. Istnieje szereg zaleceń, których uwzględnienie jest konieczne, aby skrining osiągnął swój cel $[2,3]$. Brak jednorodnej polityki w zakresie strategii realizacji badań przesiewowych prowadzi do rozbieżności w ocenie skuteczności i kosztów programów [4]. Eksperci podkreślają, że źle prowadzony skrining powoduje więcej strat niż korzyści [5], dlatego tak dużą uwagę zwraca się na konieczność systematycznej oceny efektów zdrowotnych i kosztowych, prowadzonej z zastosowaniem metod naukowych. Ocena daje podstawy do podjęcia decyzji o poprawie funkcjonowania lub zaprzestaniu działania skriningu.

Wdrażanie skriningów regulują Zalecenia Rady Unii Europejskiej z dnia 2 grudnia 2003 r. w sprawie badań przesiewowych w kierunku raka (2003/878/WE) [6]. Z uwagi na wieloaspektowość badań skriningowych opracowano europejskie rekomendacje dotyczące diagnozy i leczenia nowotworów piersi, szyjki macicy i jelita grubego, co do których istnieją dowody, że skrining populacyjny przynosi zakładany efekt [7-9]. Opracowanie tych rekomendacji zostało podkreślone w strategii dla zdrowia UE, tzw. „Białej księdze" [10], a ich wdrażanie poparły liczne rezolucje Parlamentu Europejskiego [11-13]. Polska, podobnie jak większość państw europejskich, rozpoczęła wdrażanie i utrzymuje funkcjonowanie skriningu w zakresie wyżej wymienionych nowotworów. Jednak podobnie jak w Polsce, tak i w całej Unii Europejskiej istnieją liczne modyfikacje i odejścia od zaleceń, co skutkuje obniżoną jakością całego procesu [14].

${ }^{1}$ Narodowy Instytut Zdrowia Publicznego — Państwowy Zakład Higieny

${ }^{2}$ Zakład Epidemiologii i Promocji Zdrowia, Szkoła Zdrowia Publicznego, Centrum Medyczne Kształcenia Podyplomowego 
Formułowanie rekomendacji i przeformułowanie ich tak, aby były zrozumiałe dla zainteresowanych grup odbiorców, jest dziedziną doradztwa naukowego (science advice). Doradztwo naukowe dla zdrowia jest zdefiniowane jako zamówione lub niezamówione analizy określonych kwestii zdrowia publicznego, opieki zdrowotnej lub problemów polityki zdrowotnej w oparciu o aktualną wiedzę naukową, uwzględniające istotne ekspertyzy, doświadczenie praktyczne, etyczne i kulturowe, wartości społeczne i konsekwencje wraz z wnioskami i zaleceniami w zakresie polityki zdrowotnej [15]. Europejska sieć na rzecz doradztwa nauki w kwestiach zdrowia (European Science Advisory Network for Health - EuSANH) w latach 2009-2011 realizowała projekt zatytułowany Improving Science Advice for Health in Europe (EuSANH-ISA) ze środków 7. Programu Ramowego. Wyniki projektu zostały opisane w artykule „Rola nauki w podejmowaniu decyzji politycznych — projekt EuSANH-ISA, struktura doradztwa nauki w kwestiach zdrowotnych" [16]. Efektem prac EuSANH był m.in. naukowy raport doradczy Determinants of a successful implementation of population based cancer screening programmes [5]. Z uwagi na badania ujawniające znaczne różnice między krajami europejskimi raport miał na celu analizę procesu i procedur niezbędnych do skutecznego wdrożenia programów populacyjnych. Stanowił on podstawę różnych opracowań w zakresie organizacji i prowadzenia skriningów, m.in. odwołuje się do niego w Aneksie 4. edycji European guidelines for quality assurance for breast cancer [17].

Na podstawie analizy realizowanych w Europie programów skriningowych oraz literatury przedmiotu, w tym przywoływanych powyżej rekomendacji, grupa ekspertów podzieliła realizację programu masowych badań przesiewowych na siedem etapów (tab. I).

Wynikiem prac EuSANH-ISA są również „Zalecenia dla Ministra", swoisty apel skierowany do ministrów zdrowia krajów europejskich. Stanowią one podsumowanie najważniejszych wniosków sformułowanych podczas spotkania Grupy Roboczej projektu EuSANH w dniach 7-9 lutego 2011 roku w Sztokholmie. Celem „Zaleceń” jest ułatwienie wdrażania oraz doskonalenie zorganizowanych, prowadzonych już populacyjnych badań skriningowych w kierunku wczesnego wykrywania raka szyjki macicy, piersi i jelita grubego. W nawiązaniu do kluczowych elementów poszczególnych etapów skriningu zwraca się w nich uwagę na następujące kwestie:

- podejmowanie decyzji w oparciu o istniejące dowody, zalecenia i doświadczenia;

- powołanie koordynatora działań z uwagi na wieloaspektowość procesu i jego zmienną w czasie dynamikę;

- zapewnienie środków finansowanych i organizacyjnych;

- zapewnienie, realizowanie i wyciąganie wniosków z kontroli jakości na wszystkich etapach skriningu w celu jego oceny;

- korzystanie z doświadczeń europejskich, m.in. przez kontakt z adekwatnymi organizacjami;
- regularne publikowanie sprawozdań z monitorowania skriningów oraz oceny efektów zdrowotnych;

- wykorzystanie rejestrów oraz dodatkowych narzędzi do obliczania wskaźników zdrowotnych;

- zwrócenie szczególnej uwagi na aspekty społeczne, ze szczególnym uwzględnieniem budowania zaufania społecznego w oparciu o wymianę rzetelnych informacji;

Z uwagi na znaczenie jakości skriningu dla osiągania efektów zdrowotnych i ekonomicznych, czego decydenci winni być świadomi, „Zalecenia” zostały przetłumaczone na język polski i udostępnione polskim czytelnikom w niniejszym artykule.

\section{Zalecenia dla Ministra [5]}

Każda decyzja o wprowadzeniu programu zorganizowanych masowych badań skriningowych w Europie winna uwzględniać zalecenia i wytyczne przygotowane w oparciu o dowody i doświadczenia w tym zakresie w innych krajach europejskich. Podstawowymi dokumentami dla tych zagadnień są Zalecenia Rady Unii Europejskiej z dnia 2 grudnia 2003 r. w sprawie badań przesiewowych w kierunku raka [6], European Guidelines dotyczące zapewnienia jakości skriningom w kierunku wczesnego wykrywania raka piersi, szyjki macicy i jelita grubego [7-9], a także najnowsze raporty na temat procesu wdrażania programów skriningowych w krajach Unii Europejskiej [18-20]. Wymienione dokumenty wskazują, że wartości społeczne w połączeniu z wysokim standardem merytorycznym, technicznym oraz naukowym mają nadrzędne znaczenie przy każdej decyzji zmierzającej do wdrożenia zorganizowanego programu skriningowego. Ponadto, zgodnie z zaleceniami Rady Europejskiej oraz autorami i wydawcami European Guidelines, wdrożenie zorganizowanych programów populacyjnych jest społecznie bardziej sprawiedliwe, skuteczniejsze i lepiej opłacalne kosztowo, aniżeli prowadzenie skriningu niezorganizowanego poza programem (oportunistycznego). Skrining poza programem zwykle prowadzi do nadmiernego wykorzystania zasobów zdrowotnych systemu poprzez zbyt częste badania wykonywane w części populacji z niskim ryzykiem, przy równoczesnym zaniedbaniu populacji mniej uprzywilejowanej, zwykle z wyższym ryzykiem zachorowania na chorobę nowotworową.

Doświadczenia europejskie ukazują, że skuteczne wdrażanie skriningów populacyjnych wymaga długoterminowego zaangażowania politycznego, wieloaspektowego programu zarządzania jakością oraz systematycznego finansowania. Po osiągnięciu stabilizacji dobrze zorganizowanego skriningu wydatki na zapewnienie jego jakości nie powinny być mniejsze niż 10-20\%, w zależności od zasięgu. W początkowych latach działania proporcja ta może być odpowiednio wyższa, co wiąże się z mniejszą liczbą badań w porównaniu z sytuacją, gdy cała populacja jest objęta skriningiem ogólnokrajowym. 
Tabela I. Wybrane kluczowe elementy 7 etapów organizacji skriningów

\begin{tabular}{|c|c|c|c|}
\hline 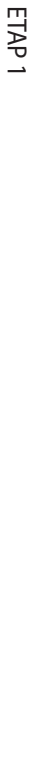 & $\begin{array}{l}\text { — przegląd literatury naukowej i istniejących wytycznych; } \\
\text { — gromadzenie informacji epidemiologicznych na temat } \\
\text { występowania choroby, stopnia zaawansowania oraz } \\
\text { przeżyć; } \\
\text { — gromadzenie informacji na temat dostępności i jakości } \\
\text { leczenia; } \\
\text { — analiza doświadczeń w tym zakresie z innych krajów; } \\
\text { — rozpowszechnianie wiedzy wśród profesjonalistów } \\
\text { i społeczeństwa na temat korzyści i zagrożeń związanych } \\
\text { z badaniami przesiewowymi; } \\
\text { — wola polityczna, zaangażowanie na wszystkich istotnych } \\
\text { poziomach (UE, państw członkowskich i regionów); } \\
\text { — decyzja o wzięciu politycznej odpowiedzialności za ten } \\
\text { proces; } \\
\text { — dostępność leczenia i możliwości zarówno w obszarze } \\
\text { kompetencji, jak i zasobów; } \\
\text { —ocena zaplecza/barier dla wdrażania zorganizowanych } \\
\text { badań przesiewowych; } \\
\text { — ocena skutków gospodarczych, opłacalności i efektywności } \\
\text { programu; } \\
\text { — formalna decyzja i przydział budżetu; } \\
\text { _organizacja ciągłej debaty społecznej o sposobie realizacji, } \\
\text { efektach zdrowotnych i kosztowych skriningu. }\end{array}$ & $\underset{\sim}{\stackrel{m}{7}}$ & $\begin{array}{l}\text { — planowanie infrastruktury; } \\
\text { — powołanie ośrodka koordynującego z uprawnieniami } \\
\text { nadzorującymi; } \\
\text { — wyznaczenie osoby odpowiedzialnej za jakość całości } \\
\text { procesu; } \\
\text { — rozwój organizacyjny (samokształcenie, nastawienie na jakość, } \\
\text { rozwiązywanie problemów, budowanie zaufania); } \\
\text { — oddzielny budżet na koordynację procesu; } \\
\text { — odpowiednia ocena jakości diagnostyki; } \\
\text { — odpowiedni system IT, monitorujący badania przesiewowe } \\
\text { z dostępem i możliwością łączenia rejestrów, np. } \\
\text { populacyjnych, rejestrów pacjentów, rejestrów nowotworów; } \\
\text { — opracowanie i przyjęcie planu zapewnienia jakości, w tym } \\
\text { jakości technicznej (QA — quality assurance); } \\
\text { — definicja parametrów pracy i dopuszczalnych poziomów, } \\
\text { w tym norm wymaganych od pracowników służby zdrowia; } \\
\text { — umowy z dostarczycielami usług medycznych; } \\
\text { — system audytu i szkoleń; } \\
\text { — narzędzia oceny do wykluczenia złych wykonawców; } \\
\text { — rozważanie systemu akredytacji lub innych kompleksowych } \\
\text { systemów dla zapewnienia właściwego świadczenia usług. }\end{array}$ \\
\hline 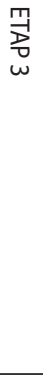 & $\begin{array}{l}\text { — przegląd protokołu wykonalności* pod kątem naukowym } \\
\text { i etycznym, jego publikacja; } \\
\text { — rzetelne i zrównoważone informacje na temat „korzyści } \\
\text { i ryzyka”; } \\
\text { — opracowanie strategii komunikacji z zaangażowanymi } \\
\text { podmiotami; } \\
\text { — zaangażowanie społeczeństwa; } \\
\text { — sprecyzowanie kwestii ochrony danych i zachowania } \\
\text { poufności; } \\
\text { — utworzenie formalnego nadzoru programów badań } \\
\text { przesiewowych. }\end{array}$ & $\begin{array}{l}\text { 罗 } \\
\text { D } \\
\Delta\end{array}$ & $\begin{array}{l}\text { — ustalenie budżetu; } \\
\text { — zapewnienie stabilnego finansowania; } \\
\text { — nadzór i kształcenie pracowników programu skriningowego; } \\
\text { — testowanie ram prawnych; } \\
\text { — możliwość wykluczenia złych wykonawców; } \\
\text { — naukowe publikacje wyników pilotażu/ów. }\end{array}$ \\
\hline \multirow[t]{2}{*}{$\underset{\text { v }}{\stackrel{\text { D }}{\overrightarrow{7}}}$} & \multirow{2}{*}{$\begin{array}{l}\text { — wyłanianie i kontraktowanie lokalnych, regionalnych } \\
\text { i krajowych zespołów programowych, określenie zakresu } \\
\text { odpowiedzialności; } \\
\text { _ infrastruktura ustanowiona dla koordynacji współpracy z } \\
\text { placówkami ochrony zdrowia; } \\
\text { _ identyfikacja ewentualnych przeszkód; } \\
\text { _ opracowanie planu ewaluacji; } \\
\text { — szkolenie specjalistyczne, centra referencyjne; } \\
\text { _ kompleksowy system informacji, łączący wszystkie etapy } \\
\text { procesu; } \\
\text { — współpraca między systemem badań przesiewowych, } \\
\text { lecznictwem i systemami informatycznymi; } \\
\text { — zmniejszanie barier dla uczestnictwa; } \\
\text { — wspieranie i współpraca z lokalnymi organizacjami } \\
\text { społeczeństwa obywatelskiego; } \\
\text { — zaufanie ludności do systemu. }\end{array}$} & $\begin{array}{l}7 \\
\frac{7}{0} \\
a\end{array}$ & $\begin{array}{l}\text { — nadzorowanie wszystkich etapów procesu; } \\
\text { - możliwość wykluczenia złych wykonawców; } \\
\text { — tworzenie możliwości do testowania nowych technologii; } \\
\text { — monitorowanie korzyści i szkód z badań przesiewowych; } \\
\text { — publikacje naukowe z wyników uzyskanych na tym etapie. }\end{array}$ \\
\hline & & $\underset{v}{\stackrel{T}{7}}$ & $\begin{array}{l}\text { — przekazywanie wyników badań przesiewowych klientom } \\
\text { w sposób dokładny i zrozumiały; } \\
\text { — budowanie zaufania wśród społeczeństwa; } \\
\text { — umocowanie organizacyjne; } \\
\text { — zapewnienie odpowiednich zasobów finansowych } \\
\text { i zaangażowania politycznego. }\end{array}$ \\
\hline
\end{tabular}

*Protokół wykonalności zawiera wyniki zebrane w czasie studium wykonalności. Celem realizacji studium wykonalności jest przede wszystkim zbadanie zasadności realizacji projektu w proponowanym kształcie.

W chwili podejmowania politycznej decyzji o wprowadzeniu zorganizowanego skriningu populacyjnego należy powołać kompetentnego koordynatora, który uzyska upoważnienia do całościowego nadzoru nad wdrażaniem jego kolejnych etapów począwszy od fazy planowania - poprzez testy wykonalności, badania pilotażowe, jak również analizę wyników etapowej oceny — do stopniowego rozwijania zasięgu działania skriningu. Jednocześnie wszystkie etapy winny być zgodne z wytycznymi oraz standardami zawartymi w Zaleceniach Rady UE z dnia 2 grudnia 2003 r. [6], European Guidelines [7-9], a także z krajowymi zaleceniami i standardami. Koordynator powinien dysponować odpowiednimi środkami finansowymi i narzędziami organizacyjnymi, które umożliwiają efektywne prowadzenie programów oraz podejmowanie dalszych niezbędnych decyzji. Decyzje te mają na celu ułatwienie koordynatorowi i całemu zespołowi dostosowanie skriningu do istniejącej sytuacji w zakresie usług medycznych. Niezależnie od istniejącej 
sytuacji w tym zakresie, organizacja oraz merytoryczne zarządzanie skriningiem musi być wyposażone w odpowiednie kompetencje oraz posiadać upoważnienie do kontroli jakości na wszystkich etapach realizacji programu, włącznie z informowaniem społeczeństwa, wysyłaniem zaproszeń do osób, do których skrining jest kierowany, wykonywaniem badań będących testem skriningowym, ustaleniem rozpoznania oraz ewentualnym leczeniem i dalszą opieką. Zdobyte w Europie doświadczenia we wdrażaniu programów skriningowych powinny być dostępne w celu wymiany informacji i doświadczeń, najlepiej za pośrednictwem europejskich sieci zorganizowanych dla potrzeb programów skriningowych koordynowanych przez Międzynarodową Agencję Badań nad Rakiem (IARC) oraz w celu aktualizacji wytycznych zawartych w European Guidelines, a także w celu umożliwienia dalszego rozwoju inicjatyw, takich jak Europejskie Partnerstwo Na Rzecz Walki z Rakiem (EPAAC, www.epaac.eu).

W celu prawidłowego monitorowania oraz oceny jakości i wyników zdrowotnych zorganizowanego skriningu populacyjnego konieczne jest wykorzystanie rejestrów oraz dodatkowych narzędzi, które umożliwiałyby powiązanie indywidualnych danych o zachorowaniu na raka i przebiegu choroby, historii wykonywania badań w ramach skriningu, rozpoznaniu, leczeniu oraz informacji, czy chory żyje, a jeżeli zmarł - o przyczynie i dacie zgonu. Ponadto kluczowe wskaźniki wykonania i jakości całego procesu skriningu muszą być rejestrowane i monitorowane, a wyniki analizowane i wykorzystywane do oceny jakości jego realizacji. Sprawozdania obejmujące wyniki monitorowania oraz efekty zdrowotne skriningów muszą być regularnie publikowane w celu informowania opinii publicznej oraz osób podejmujących decyzje w tym zakresie, ażeby umożliwić modyfikację skriningu we właściwym czasie, jeśli okaże się ona konieczna. Doświadczenie, jakim dysponuje EuSANH w rozwijaniu doradztwa w zakresie budowania polityki zdrowotnej, bierze pod uwagę nie tylko aspekty naukowe czy merytoryczne, lecz także społeczne, które mają duże znaczenie w tej dziedzinie.

\section{Konflikt interesu: nie zgłaszono}

\section{Dr hab. n. med. Magdalena Bielska-Lasota}

Narodowy Instytut Zdrowia Publicznego — Państwowy Zakład Higieny ul. Chocimska 24, 00-791 Warszawa

e-mail:mbielska@pzh.gov.pl

Otrzymano i przyjęto do druku: 23 lipca 2014 r.

\section{Piśmiennictwo}

1. Dane EUROSTAT. Pobrane 1.04.2014 r: http://epp.eurostat.ec.europa. eu/statistics_explained/index.php/Causes_of_death_statistics

2. Lynge E, Törnberg S, von Karsa L i wsp. Determinants of successful implementation of population-based cancer screening programmes. Eur J Cancer 2012; 48: 743-748.

3. Wilson JMG, Jungner G. Principles and practice of screening for disease. Genewa:WHO; 1968.

4. Bielska-Lasota M. Przyczyny niskiej wyleczalności chorych na raka szyjki macicy w Polsce. Warszawa: Centrum Onkologii-Instytut im. Marii Skłodowskiej-Curie; 2006.

5. Anttila A, Bielska-Lasota M, Davidson T i wsp. Stockholm statement on successful implementation of population-based cancer screening programmes. Determinants for a successful implementation of population-based cancer screening programmes. Sztokholm: EuSANH; 2011.

6. Zalecenie Rady UEz dnia 2 grudnia 2003 r.w sprawie badań przesiewowych w kierunku raka (2003/878/WE): Dz.U. L 327/34-38.

7. Perry N, Broeders M, de Wolf C i wsp. European guidelines for quality assurance in breast cancer screening and diagnosis. 4th ed. Luxembourg: Office for official publications of the European Communities; 2006.

8. Arbyn M, Anttila A, Jordan J i wsp. European guidelines for quality assurance in cervical cancer screening. 2nd ed. Luxembourg: Office for official publications of the European Communities; 2008.

9. Segnan N, Patnick J, von Karsa L. European guidelines for quality assurance in colorectal cancer screening and diagnosis. Luxembourg: Publication office of the European Union; 2010.

10. Razem na rzecz zdrowia: Strategiczne podejście dla UE na lata 2008-2013. COM(2007) 630 wersja ostateczna z 23.10.2007. Pobrano 4.04.2014 http://ec.europa.eu/health/archive/ph_overview/documents/strategy_wp_pl.pdf.

11. Rezolucja Parlamentu Europejskiego z dnia 5 czerwca 2003 r. w sprawie raka piersi w Unii Europejskiej (P5_TA(2003)0270), Dz.U. C 68 E z 18.3.2004, s. 611.

12. Rezolucja Parlamentu Europejskiego z dnia 25 października 2006 r. w sprawie raka piersi w rozszerzonej Unii Europejskiej (P6_TA(2006)0449 B6-0528/2006): Dz.U. C 313 E z 20.12.2006, s. 273.

13. Rezolucja Parlamentu Europejskiego z dnia 10 kwietnia 2008 r. W sprawie zwalczania nowotworów w rozszerzonej Unii Europejskiej (P6 TA(2008)0121).

14. Deandrea S. Presentation of comparison of quality assurance schemes for breast cancer services in Europe. The European Commission Joint Research Centre. Workshop. Ispra, 21-22 February, 2013. Dostępne na: www.jrc.ec.europa.eu.

15. Sarria-Santamera A, Schoten EJ, Coenen TM i wsp. A framework for scientific advice on health: EuSANH's principles and guidelines. Health Res Policy Sys 2013; 11: 6

16. Cianciara D, Piotrowicz M, Bielska-Lasota M i wsp. Rola nauki w podejmowaniu decyzji politycznych - projekt EuSANH-ISA, struktura doradztwa nauki w kwestiach zdrowotnych. Przegl Epidemiol 2012; 66: 521-529.

17. von Karsa L, Anttila A, Primic Žakelj M i wsp. Stockholm statement on successful implementation of population-based cancer screening programmes. W: Perry N, Broeders $\mathrm{M}$, de Wolf C i wsp. (red.). European guidelines for quality assurance in breast cancer screening and diagnosis. 4th ed., Supplements. Luxemburg: European Commission, Office for Official Publications of the European Union, 2013, s. 123-128.

18. Anttila A, Ronco G; Working Group on the Registration and Monitoring of Cervical Cancer Screening Programmes in the European Union within the European Network for Information on Cancer (EUNICE). Description of the national situation of cervical cancer screening in the member states of the European Union. EJC 2009; 45: 2685-2708.

19. von Karsa L, Anttila A, Ronco G i wsp. (2008). Cancer screening in the European Union, Report on the implementation of the Council Recommendation on cancer screening - First Report. European Communities. Luxemburg: International Agency for Research on Cancer, 2008.

20. Report from the Commission to the Council, the European Parliament, the European Economic and Social Committee and the Committee of the Regions - Implementation of the Council Recommendation of 2 December 2003 on cancer screening (2003/878/EC). Brussels: Commission of the European Communities, 2008. 